\title{
TURKEY'S COFFEE ADVENTURE: AN ANALYSIS OF COFFEE EXPERIENCE TYPOLOGIES AND BUSINESS TYPE PREFERENCES
}

\author{
Bahar BAYINDIR \\ Department of Gastronomy and Culinary Arts, Kırklareli University, Turkey \\ ORCID: 0000-0002-6440-1132 \\ Osman ÇALIŞKAN ${ }^{1}$ \\ Department of Gastronomy and Culinary Arts, Tourism Faculty, Akdeniz University, Turkey \\ ORCID: 0000-0002-7802-0816
}

\begin{abstract}
The rise in the coffee consumption, as one of the most popular beverages in the world, has opened the door to "coffee shops" in their modern form. The present study analyses the type of Turkish consumers who prefer national and international coffee shops based on their demographic characteristics and motivations. A total of 448 visitors to coffee shops during the Istanbul Coffee Festival filled out the developed survey form. 411 of these were used for data analysis. The data obtained in the research were divided into four groups through a Chi-squared Automatic Interaction Detection (CHAID) Analysis and Correspondence Analysis, depending on the demographic and motivational characteristics of the consumers with experience of national and international coffee shops. Consumers attribute importance to the atmosphere, image, coffee quality and location of coffees shops, while the target market of coffee shops is generally well-educated, consisting of mostly female consumers over the age of 30 . The first and the second group preferred the coffee experience of international coffee shops, while the third group preferred only national coffee shops. The respondents in the fourth group preferred the national coffee shops, but also stated a desire to experience coffee in international coffee shops.
\end{abstract}

\section{Article History}

Received 19 April 2021

Revised 19 August 2021

Accepted 7 September 2021

Published online 13 Oct. 2021

\section{Keywords}

coffee

coffee shops

correspondence analysis

coffee experience typologies

CHAID analysis

\footnotetext{
${ }^{1}$ Address correspondence to Osman Çalışkan (PhD), Department of Gastronomy and Culinary Arts, Tourism Faculty, Akdeniz University, Antalya, Turkey. E-mail: ocaliskan@akdeniz.edu.tr
} 


\section{INTRODUCTION}

The coffee experience has been affected by periods of modernization and change in recent years, and, with a Western style, it has entered a new period of change (Hu \& Lee, 2019; Spence \& Carvalho, 2020). According to this change people started to consume different types of coffee, and to experience the new-generation coffee trends (Brown, 2018). This change has not affected only coffee consumption habits, but also locations where the coffee is consumed. "Coffee Shops" emerged in the modern sense after coffee started to be affected by consumption patterns (White, 2012). Although coffee shops seem to be the places where people meet their need for food and drink, they also include a socialization aspect, which is another basic need. Coffee shops offer the spatial means for the development of social relations, as places where people meet and interact (Çakı \& Kızlltepe, 2017).

Grigg's (2003) analysis of the coffee consumption found that it is consumed in many countries, but that its popularity changes from country to country. He states that coffee consumption was limited to the Islamic world until the early 18th century, but that today it is consumed more in Europe and America. In Turkey, Turkish coffee is what first comes to one's mind when talking about coffee (Özcan, 2016). However, the recent arrival of global coffee shop chains has induced an increase in similar local chains established by Turkish entrepreneurs, with various types of coffee being included on their menus. With the rise in number of such coffee shops, different types of coffee have started to be consumed in large quantities, along with Turkish coffee. In particular, espresso, latte, cappuccino, drip coffee, etc., known collectively as European coffees, have started to be consumed by many consumers in daily life in Turkey.

Coffee shops, with customer portfolios of all ages and from all levels of the social strata, sell not only the products on their menus, but also an atmosphere in which people feel comfortable (Spence \& Carvalho, 2020). In order to pull more customers in, coffee shops provide services such as Internet access for those clients who wish to use computers while enjoying in music and a cup of coffee (Said, 2012; Susanty \& Kenny, 2015). Thus, it can be concluded that consumer preferences for coffee shops are attributable to a variety of factors (Filimonau et al., 2019). Firstly, consuming hot drinks in coffee shops as Oldendurg's "third places" has become a routine for consumers (Kanjanakom \& Lee, 2017); secondly, coffee shops provide the opportunity to try unique and high quality drinks that are hard to prepare at home (Glazer, 2015); thirdly, coffee shops increase 
customer loyalty by encouraging revisits through quality customer service and novel experiences (Aries \& Eirene, 2015); fourthly, coffee shops provide comfortable spaces in which people can socialise and conduct business interviews (Yu \& Fang, 2009); and finally, consumers consider going to coffee shops since these are offering them a means of expressing themselves, and may represent a sign of status in social life, which is an aspect that significantly affects the success of coffee shops (Aşık, 2017; Kang et al., 2011).

Coffee itself has played an important role in politic, economic, and cultural terms, both in the past and present. This has gradually increased under the effect of its shaping of social and cultural life along with its consumption as a drink (Alyakut, 2017). Importance of coffee has led to an abundance of studies of coffee and coffee shops. As the popularity and importance of coffee have increased, many studies have been conducted to understand the consumption of coffee and coffee shops in recent years (Aşık, 2017; Samoggia \& Riedel, 2018). An examination of these studies reveals that these studies of coffee and coffee consumption have focused on the adventure of coffee from past to the present, the coffee culture and sustainability issues (Argan et al., 2015; Grinshpun, 2014; Schüßler, 2009), while other studies have focused rather on the results of behaviours (satisfaction, the continuation of the behaviour in the future, etc.) (Kim, 2008; Ko \& Chiu, 2008; Nadiri \& Günay, 2013; Yan \& Li, 2016).

Pozos-Brewer (2015) found that every coffee and coffee shop movement address different demographic characteristics and different lifestyles. It has been further stated that coffee drinking habits, and their hedonic and pragmatic consumption motivations, are different from consumer to consumer (Labbe et al., 2016), and that the participation of consumers in the coffee drinking culture varies considerably from person to person (Kim et al., 2016).

Typology refers to compartmentalisation as a means of determining and distinguishing between types of humans. The main purpose of consumer-oriented typology studies in the field of marketing is to separate consumers into specific classes based on such variables as demographics, psychological profile, behaviour and consumption characteristics (Şimşir, 2018). Thanks to the determined typologies, market segmentation can be structured correctly and consistently. Gathering of consumers with similar preferences into homogeneous groups provides businesses with the opportunity to apply special marketing strategies to consumer groups based on their preferences. In this way, the satisfaction of not only the 
consumers, but also the enterprise in question increases significantly through the application of more effective marketing practices (Karadaşl, 2019).

An analysis of tourism and gastronomy literature reveals that typology studies are used to segment the target market (Phillip et al., 2010). There have been few studies to date investigating the typology of consumers with coffee experience and investigating coffee shop preferences. To address this gap in literature, the present study determines consumer typologies, including demographic characteristics and motivations of the consumers who prefer coffee shops with rich historical, cultural, social, and economic characteristics.

\section{LITERATURE REVIEW}

People prefer spaces that meet their need to feel good about themselves and become loyal. Oldendurg (1989), who developed the third-place concept (referring to places where people spend time), states that people who repeatedly travel between home and work become bored. Thus, they are in need of third places that they can easily reach during the day, and where they can meet their socialisation needs. According to Oldenburg (1989), coffee shops can be considered as third places, being an alternative to home and workplace, where people can socialise and relax.

Fendal (2007) claims that coffee and coffee shops with local cultural characteristics have been affected by consumption patterns and entered into a period of significant change. Such coffee shops that have been affected by the consumption patterns have started to convert into coffee shops in the modern sense by developing both their appearance and their physical structures, along with the service and the product range they provide. With the rise of modernism, coffee shops have become important spaces in the hearts of cities, where the masses can congregate away from their private spaces (Manzo, 2014). These spaces accompany the ordinary flow of daily life, and also function as a space for relief, relaxation, escape, freedom, etc. (Aytaç, 2007).

Woldoff et al. (2013) notes that coffee shops have grown into big companies from small businesses, with some of them becoming chains. It has also been stated that coffee shops have come to meet social expectations, aside from being Oldenburg's "third place". The second wave coffee movement period has seen coffee shops opening in many countries (Coffeemag, 2016). Cafes in Turkey have now come to be referred to as 
"coffee shops", existing alongside the "coffee shops" coming from the West. Coffee shops in which many types of coffee are sold, prepared, served and drunk have established an important place in the city centres in Turkey as spaces where people can socialise economically (Tucker, 2011). National coffee shop chains have increased in recent years in Turkey alongside the rise in international coffee shop chains. With the rise of a coffee culture, both national and international coffee shops are commonly preferred by consumers and maintain their existence as an expanding field within Turkey's consumption culture (Aydın \& Bakır, 2016). In Turkey, coffee shops are frequently located in thoroughfares, shopping centres, airports, on many university campuses and on city coastlines. Due to the different atmosphere, they cultivate, coffee shops are not just places that sell coffee, but social spaces that represent an alternative to the people's ordinary lifestyles.

The coffee shop experience is a hedonic and pragmatic source of motivation for consumers. The coffee drinking motivations of consumers in coffee shops differ from person to person (Labbe et al., 2016). In the Bourdieu's study Distinction, he argues that, when it comes to eatingdrinking style, music taste, and clothing, taste patterns bring together consumers with similar preferences and behaviours, while those with different tastes differ or separate from each other (Arun, 2013; Bourdieu, 1984). At this point, it is assumed that the demographic and socio-economic characteristics of the consumers, as well as their tastes, will affect their coffee shop preferences. Determining the typologies of coffee shop users will help clarify their individual preferences and allow coffee shops managers to prepare appropriate marketing strategies. In this process, grouping coffee shop consumers with similar characteristics in terms of behaviours, motives and product expectations is of great importance as it will assist in effectively meeting desires and expectations of each market segment.

Typology studies are frequently used in marketing for the categorisation of consumers into homogeneous groups to aid the development of market targeting, segmentation and positioning strategies (Decrop \& Snelders, 2005). Specific variables such as demographic (age, gender, education), socio-economic (income, occupation) and psychographic (motivation, beliefs, personality) are used to determine a consumer typology. Age, gender, marital status, education level and socioeconomic status are important variables explaining different food-beverage consumption habits. In a review of literature in the present study, research paper determining different typologies of coffee consumers was not 
identified. While there were studies that investigated differences in demographic characteristics, there were no studies revealing the typologies of consumer preferences related to coffees shops. Therefore, in order to determine the typologies of consumers in the rapidly growing coffee market and to understand their consumption behaviour, examining the motivations of consumers regarding their coffee shop experience, along with demographic and socio-economic variables, will provide clearer and more significant results.

In line with the current study's goal, studies that take into account the demographic variables and motivations of consumers who prefer coffee shops were examined. Shaker and Rath (2019) stated that those who prefer international coffee shops have generally high levels of cognitive and cultural skills; they are mostly young, well-educated, environmentally conscious and have good financial situation; and they seek authenticity. Kim and Jang (2017) found that companies referred to as international coffee shops are generally preferred by young consumers, who find it easy to express themselves in such establishments, seeing these as a means of connecting to the desired lifestyle symbols. Moreover, it was also found that women prefer international coffee shops more than men, with the type of coffee shop not being of great importance for men.

Zhang et al. (2019) analysed the attitudes and behaviours of consumers with coffee shop experience, and found that the coffee quality, service quality and atmosphere were all important for customer satisfaction and loyalty. A comparison of different consumer groups has been presented in the current study, with the recommendations made to coffee shop managers on how to establish more effective marketing strategies. It has been stated that young consumers are not loyal to coffee shops and may visit different coffee shops in search for different coffee shop experiences. For this reason, offering incentives such as free Wi-Fi or giving importance to social media marketing strategies are considered as important factors in ensuring the loyalty of young customers.

\section{METHODOLOGY}

In parallel with the change in purchasing power within Turkey's food and beverage culture, coffee has witnessed an increase in popularity. With the rising consumption mentality of sitting and chatting in coffee shops, consumption in locations such as home, workplace and school has increased as well (Akarçay, 2012; Aşık, 2017). Recently, number of national and international coffee shops has increased, significantly changing coffee 
consumption habits. As a result of this change, the interest of consumers in coffee shops and new coffee types has also increased significantly. It is thought that consumers who are motivated to drink coffee in coffee shops may have different coffee consumption habits. In the present study, an attempt is made to clarify the different consumer typologies based on their demographic characteristics and motivations.

The survey technique, which is an important factor in quantitative research, was used for the collection of data, being deemed appropriate for the research goal. The questionnaire contained items on the frequency of going to coffee shops, the preferred coffee shop type, the types of beverages consumed and the primary motivations for visiting coffee shops, alongside items to determine the demographic characteristics of the respondents. For the questions and statements in the survey, Kanjanakom and Lee (2017) and Jang et al. (2015) studies have been used. The menus of coffee shops were used for the following question "What type of beverage do you usually prefer in coffee shops?". In addition to four expressions derived based on experts' opinion, three more statements were added for question "Which factor do you pay attention to when choosing coffee shops?" and these are: "Employees", "Business Image" and "Products other than coffee".

In the scope of the research consumers who drink coffee in coffee houses were determined as a sample. Initially, in accordance with the purpose of the study, the survey questionnaire was meant to be applied on consumers who came to the coffee shops. However, coffee shop managers did not accept conducting of a survey in their properties, anticipating that customers might be disturbed and might have negative thoughts about the company. Since it was difficult and costly to reach coffee shops and their customers, the participants of the Istanbul Coffee Festival, which was held in Istanbul on 21-24 September 2017, and which brought together many coffee brands, coffee shops and thousands of coffee consumers, were considered suitable for the scope and purpose of the current research. Data was collected from attendees of the $4^{\text {th }}$ Istanbul Coffee Festival using a survey form and a convenience sampling method, with voluntary participation. During the festival day there were two sessions, each lasting for four hours. Time between 14:00 and 15:00 was used for baristas to have a break, to clean the coffee counters and to prepare for the next session. At this time, the participants usually sat with their friends or families on cushions and chairs in the grass area reserved for rest. Since this was the time when festival attendees did not join any of the seminars, workshops and coffee tasting practices, it was suitable for the researchers to reach the potential survey participants in a more convenient and comfortable 
environment. During data collection process, face-to-face interviews were conducted with the participants, and they were asked to fill out the questionnaire. Of the 448 respondents who filled out the questionnaire, 37 were excluded from the study due to incorrect or incomplete forms, meaning that 411 survey forms were included in the analysis.

In accordance with the research aim, various statistical procedures were followed. As a first step, the frequency and percentage distributions were examined while evaluating the responses given to the statements about the participants' motivation for visiting coffee shops.

Second, demographic characteristics that differentiate participants' reasons to prefer coffee shops were identified with using a decision tree algorithm. The age, education level and income data of the Turkish customers consuming coffee in national and international coffee shops were classified with the CHAID, and the independent variables that were effective in this classification were determined. CHAID analyses are used for the classification of variables. As an explanatory approach, CHAID analysis is used in studies aimed at determining the relationships between a dependent variable and a series of independent variables (Doğan \& Özdamar, 2003). The groups demonstrating differences are grouped based on their relationship level using a Chi-square metric, with the leaves of the tree branching based on the number of different structures in the data (Demirel, 2010; Aksu \& Karaman, 2016). A correspondence analysis was then applied to explain the relationship between the categorical variables in the data matrix in complex structure with graphic and matrix in a more comprehensible and simpler structure.

A Correspondence Analysis is a descriptive multivariate statistical method that is used in situations where there is a need to examine the relationships between variables with crosstabs in two or more dimensions (Y1ldiztekin, 2016). At the end of the analysis, the relationships between the categories of each variable in the crosstabs with two or more variables are examined graphically and interpreted (Alpar, 2013). Similar categories in the graphic are positioned closer, while incompatible structures are positioned at more distant points (Clausen, 1998). In the correspondence analysis, the interrupted continuous numeric data which are characteristics or made characteristics are used. In the analysis, first, the categorical profiles are calculated, followed by the weights, and finally the distances between points for the row and column categories. The row and column categories are formed by specifying the frequencies in the crosstabs. The distances are the Euclid and Chi-square distances. The equivalence of 
variance in a correspondence analysis is the phrase "inertia", being the total measure of the distances between the profile points and the centre. As the total inertia value comes closer to zero, the column profiles are gathered in the centre, and move away from the centre otherwise. Multiple correspondence analyses were used to determine the typologies of Turkish customers' demographic characteristics and motivations.

\section{RESULTS}

The results related to gender, marital status, age, educational status, and monthly income of the respondents are presented in Table 1, while the finding of frequency of coffee shop visits, the preferred coffee shop type, the type of beverages consumed, and the effective factors in coffee shop preferences are presented in Table 2.

Table 1. Demographic Characteristics of the Respondents

\begin{tabular}{lcc}
\hline Gender & Frequency (n) & Percentage (\%) \\
Female & 217 & 52.8 \\
Male & 194 & 47.2 \\
Total & 411 & 100 \\
\hline Marital status & & \\
Single & 250 & 60.8 \\
Married & 161 & 39.2 \\
Total & 411 & 100 \\
\hline Age & & \\
18-23 & 119 & 29.0 \\
24-29 & 164 & 39.9 \\
30-35 & 64 & 15,6 \\
36-41 & 30 & 7.3 \\
42-47 & 26 & 6.3 \\
48 and above & 8 & 1.9 \\
Total & 411 & 100 \\
\hline Educational Status & & \\
Primary school & 9 & 2.2 \\
Secondary School & 34 & 8.3 \\
High school & 101 & 24.6 \\
Associate degree & 37 & 9.0 \\
Undergraduate & 173 & 42.1 \\
Graduate & 57 & 13.9 \\
Total & 411 & 100 \\
\hline Monthly Income Status & & \\
Less than 1000 TL & 85 & 20.7 \\
1000-2000 TL & 102 & 24.8 \\
2001-3000 TL & 81 & 19.7 \\
3001-4000 TL & 45 & 10.9 \\
More than 4000 TL & 98 & 23.8 \\
Total & 411 & 100 \\
\hline & & \\
& &
\end{tabular}


As can be seen in Table 1, 52.8\% of the participants were female, $60.8 \%$ were single, $39.9 \%$ were within the $24-29$ age range, and $42.1 \%$ had a bachelor's degree. When the average monthly incomes were examined, it was observed that $24.8 \%$ of the respondents had a monthly income of between 1000 and 2000 TL.

Table 2. Coffee Drinking Habits in Coffee Shops

\begin{tabular}{lcc}
\hline Frequency of Coffee Shop Visits & Frequency (n) & Percentage (\%) \\
\hline Once a month & 87 & 21.2 \\
1-2 times a week & 170 & 41.4 \\
3-4 times a week & 79 & 19.2 \\
Once a day & 47 & 11.4 \\
Twice a day or more & 26 & 6.3 \\
Other & 2 & 0.5 \\
Total & 411 & 100 \\
\hline Preferred Coffee Shop Type & & \\
National & 203 & 49.4 \\
International & 208 & 50.6 \\
Total & 411 & 100 \\
\hline Preferred Coffee Type & & \\
Turkish coffee or its varieties & 135 & 32.8 \\
Espresso or espresso-based beverages & 171 & 41.6 \\
Granulated, instant coffee & 19 & 4,6 \\
Drip Coffee & 57 & 13.9 \\
Other & 29 & 7.1 \\
Total & 411 & 100 \\
\hline Factors Effective in Coffee Shop Preferences & & \\
Coffee quality & 149 & 36.5 \\
Atmosphere & 84 & 20.6 \\
Service quality & 71 & 17.3 \\
Location & 32 & 7.8 \\
Employees & 37 & 9 \\
Business image & 16 & 3,9 \\
By-products apart from coffee & 19 & 4.9 \\
Total & 411 & 100 \\
\hline
\end{tabular}

It can be seen from Table 2 that $41.4 \%$ of the respondents frequented coffee shops 1-2 times a week, $50.6 \%$ of them preferred international coffee shops and $41.6 \%$ opted for espresso or espresso-based beverages. Furthermore, $36.5 \%$ of the respondents gave priority to coffee quality in their coffee shop preferences; $20.6 \%$ to the atmosphere, $17.3 \%$ to service quality, $9 \%$ to location, $4.9 \%$ to the products on sale other than coffee, and finally, 3.9\% prioritised the business image. The three participants who marked the "other" option stated that their preference was based on campaigns. 
The respondents were asked about their motivations for going to coffee shops with open-ended questions. Among the motivations for going to coffee shops were: to drink coffee, to socialise and to rest/work, and these were included in the analysis.

Prior to the correspondence analysis, a Chi-squared Automatic Interaction Detection (CHAID) analysis was performed, primarily to provide an income classification in accordance with the context. The division structures in the independent variables making significant difference for the dependent variable were determined by CHAID analysis.

A further CHAID analysis was carried out to examine the incomebased breakdown of the socialisation, rest/work, and drinking coffee motivations. The income-based breakdown related to socialisation motivation was found to be statistically significant (F: 6,422, $\mathrm{df}=409$, $\mathrm{p}=0.047$ ). For the income-based breakdown, income was divided into two categories, being 2000 TL and below and over 2000 TL, and included in the correspondence analysis.

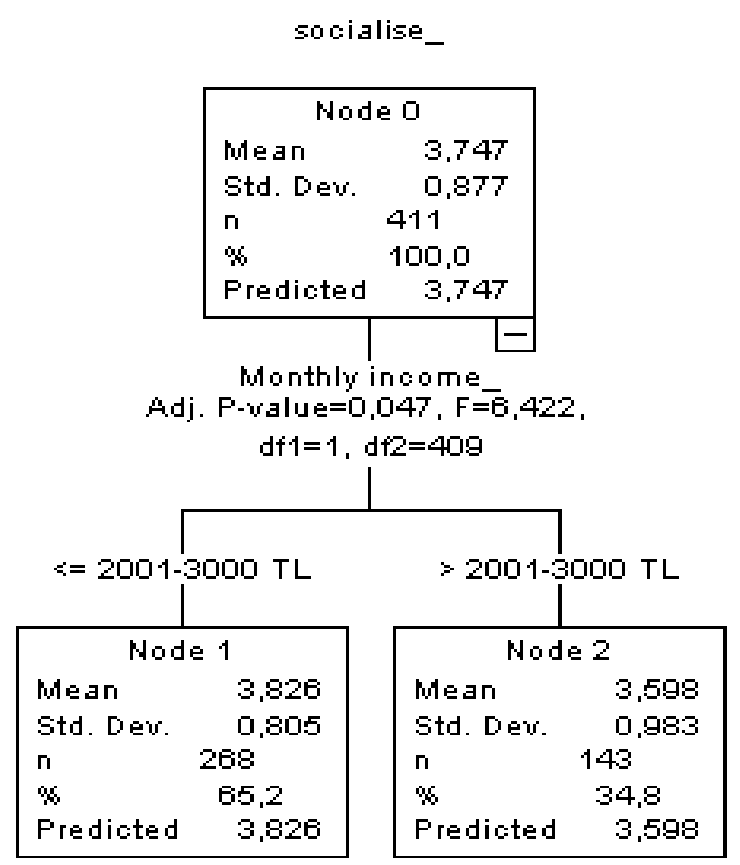

Figure 1. CHAID Analysis Results

The findings of the multiple correspondence analyses, conducted to determine the typologies of the demographic characteristics and 
motivations of the Turkish customers and their preferences for national and international coffee shops, are demonstrated in Graphic 1.

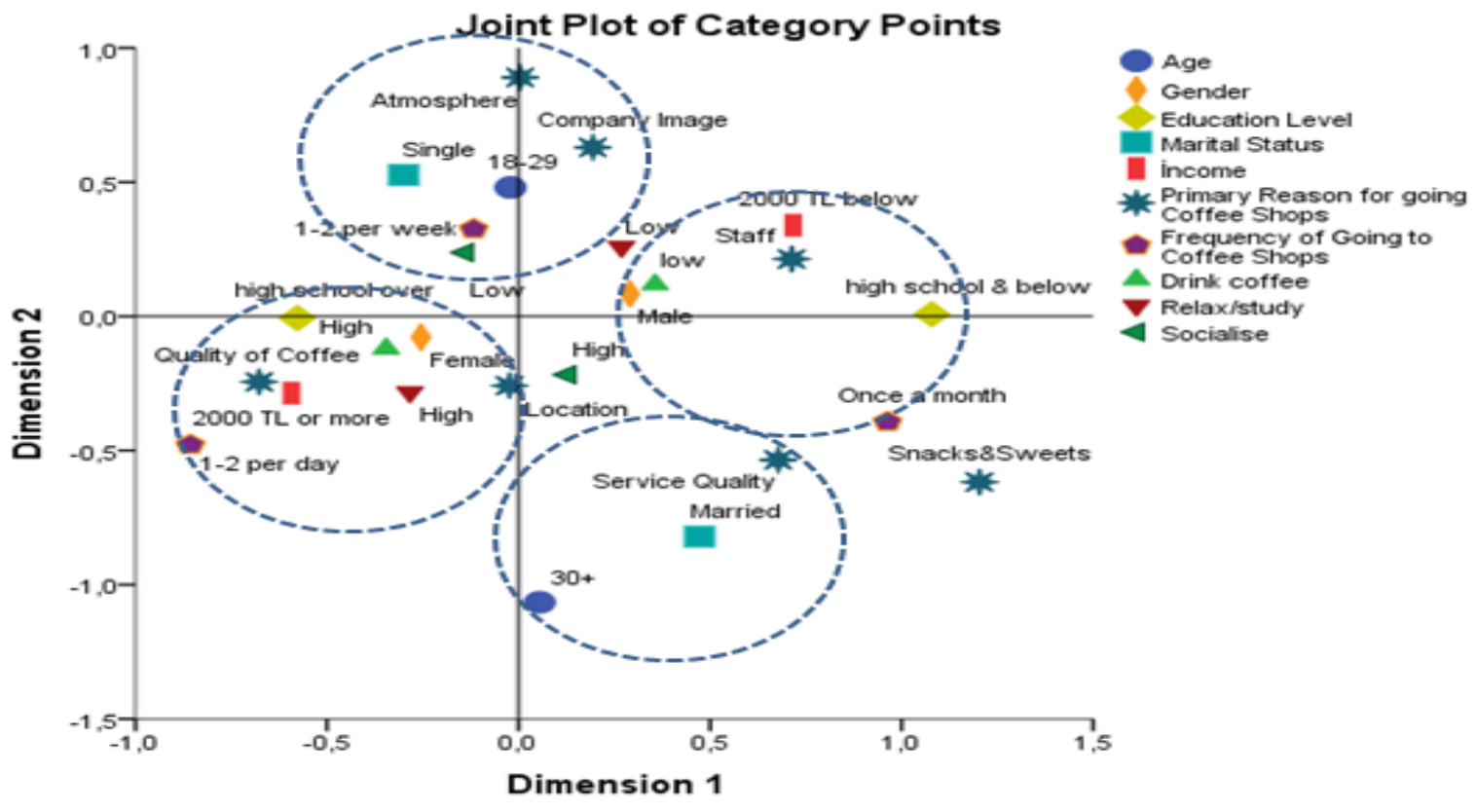

Graphic 1. Coffee experience typologies and coffee shop types (correspondence analysis)

Four groups were formed based on the results of the correspondence analysis.

The first group was composed of consumers between the ages of 18 and 29, who were single, well-educated and preferred going to coffee shops 1-2 times a week. The consumers included in this group generally frequented coffee shops for socialisation. The coffee shop type they preferred was international coffee shops. The most important factors influencing their frequenting of coffee shops were atmosphere and business image.

The second group was composed of consumers with an income over 2000 TL, who were mostly women, and who preferred going to coffee shops once a day or more. Those included in this group preferred international coffee shops. They generally went to coffee shops to drink coffee, to rest and to study. The most influential factors affecting the coffee shop preferences of the people in this group were location and coffee quality.

The third group was composed of poorly educated people with an income lower than 2000 TL who were mostly men, and the consumers in this group tended to prefer national coffee shops. It was observed that these 
consumers generally went to coffee shops to drink coffee, and only a few times a month. The most important motivation for these consumers in their coffee shop preferences was the employee profile.

The fourth group was composed of married consumers over the age of 30 who frequented both national and international coffee shops equally. Service quality was the most important factor affecting their coffee shop patronage.

\section{DISCUSSION AND CONCLUSIONS}

In this study, different consumer typologies were tried to be clarified based on their demographic characteristics and motivations. For this purpose, analyses were carried out with the data obtained from the participants. The correspondence analysis identified four groups. The first and the second group preferred consuming their coffee in international coffee shops, while the third group preferred the coffee experience of national coffee shops. The respondents in the fourth group preferred national coffee shops, but also stated a desire for coffee experience in the international coffee shops.

Consumers in the first group are young, educated, single and frequently visiting international coffee shops. Starbucks, which is the international coffee shop chain with the most branches in Turkey, is shown as one of the most successful representatives of the global and standardized coffee flavour with its distinct atmosphere (Kaptan, 2013). Consumers in this group generally prefer international coffee shops such as Starbucks because they are open to different coffee experiences and pay attention to atmosphere. Samoggia and Riedel (2018) found that the consumers generally prefer coffee shops in groups and for socialising, which they attributed to the modern lifestyle and the desire for social status. In their study on examining the relationship between lifestyle and coffee consumption, Limón-Rivera et al. (2017) found that coffee shops are often preferred by young consumers. Although coffee shops are places where people of all ages can go, Aydin and Bakir (2016) point out that these are frequently visited by university students.

In his study examining the effect of globalization on coffee shops, Typaldos (2016) emphasized that consumers who prefer coffee shop generally want to enjoy in its atmosphere. While investigating the aspects of coffee shops that affect the coffee drinking experience, Spence and Carvalho (2020) found atmosphere to be an important factor for consumers in their coffee shop experience. It has been stated that interest in coffee 
shops is increased when the coffee shop manager takes the atmosphere into consideration and makes the appropriate arrangements. Wakefield and Blodgett (1996) found that décor increases the quality of coffee shops, with consumers spending more time in these due to atmosphere, while also contributing to return custom. However, it was observed that every coffee shop that takes consumer preferences into consideration develops its own marketing strategies, aiming to increase customer loyalty to their trademarks by providing customer satisfaction, offering the highest quality coffee with the largest range, providing a comfortable environment, being environmental-friendly and using energy resources efficiently (Kadığlu, 2017).

As the consumers in the first group give importance to atmosphere and business image, an interior design that allows them to socialise may be prepared by investing into the international coffee shop concept through franchising. Loyalty to a coffee shop that reflects the style of the consumers may be provided with a more modern atmosphere. This customer profile aged 18-29, may be reached faster by making use of the social aspect and atmosphere of the venue, promoted through social media.

It was observed that the high-income consumers included in the second group preferred coffee shops generally for work and rest. The consumers in this group paid attention to coffee quality. Kim et al. (2014) examined whether there is any difference in the behaviour of coffee shop consumers according to monthly income. As a result of the findings, it was found that high-income consumers pay more attention to the brand and quality of the product than low-income consumers. Samoggia and Riedel (2018) found that the consumption of high-quality branded coffee is generally preferred by high-income consumers. The analyses in the present study revealed that the consumers included in the second group, with an income over $2000 \mathrm{TL}$, paid attention to coffee quality in their coffee shop preferences.

Communication with the employees was important for the consumers in the third group. An employee of a coffee shop may be a critical source for obtaining information on, for example, the wishes and expectations of the consumers in this group. The most appropriate information system will be provided for coffee shop managers by providing in-service training in such areas as effective communication and persuasion methods to employees. That said, as these consumers have low income, and in accordance with the likelihood that these consumers will consume only a limited amount of coffee, good pricing strategies are required if the 
profitability of the coffee shop is to be assured. For example, coffee sales may be increased through psychological pricing, while pricing strategies may be used more effectively in coffee-related promotions and campaigns in coffee shops.

As the consumers included in the fourth group, who were married and over the age of 30 , gave more importance to family ties, they tended to visit coffee shops to spend time with their families. One of the most important demographic characteristics that affect consumers' purchasing decisions is age (Kotler, 2000). Each age has its own expectations, experiences, lifestyles, and values, and all these factors are an important factor in the behaviour of consumers (Sarıtaş \& Barutçu, 2016). In his study, Yazici (2018) stated that quality is the most important factor in product and service for Y-generation consumers. Spence and Carvalho (2020) found that consumers of advanced ages preferred coffee shops with comfortable armchairs and chairs, without loud music, and with more space between tables. These customers pay attention to the way employees take orders at the table and prefer their orders to be served to their table in porcelain or glass. In their study, Acar et al. (2019) found that married consumers attribute more importance to the physical characteristics of coffee shops. Coffee shop managers should pay attention to details that provide customer satisfaction, especially for those consumers who prioritise service quality.

The results of the present study may contribute to the success of coffee shops operating in the sector by providing information on customer profiles and the strategies to be developed to meet customer expectations. It is understood that a coffee shop owner, manager or employee may be able to recognise consumer characteristics, and address and shape how they deliver service quality in accordance with these characteristics. Thus, it may be useful to make some recommendations to entrepreneur owners and managers of national and international coffee shop about customer profiles and their target markets. Consumers attribute importance to the atmosphere, image, coffee quality and location of coffees shops. The target market of these kinds of coffee shops is generally well-educated, mostly female consumers over the age of 30 . Atmosphere, business image, location, and coffee quality influence customer preferences of international coffee shops, and this can guide managers in reaching their target profitability. For example, attention may be paid to the harmony of the atmosphere, image, location, concept, physical characteristics, menu, table settings, employee uniforms and interior designs; or promotions and campaigns may be launched that are suitable for the target market, encouraging the return custom of those who visit coffee shops at least a few times a day. When 
developing a new product, they may be designed to suit the customer profile and to be included on the menu.

As in every research, this study has some limitations, the main limitation is the scope of the research. The research population were visitors of the Istanbul Coffee Festival, and further detailed and more comprehensive studies may be conducted with a different sample, involving coffee shops located in different cities or those of a specific brand. Furthermore, the research may be extended through the addition of other demographic variables and coffee experience motivations. Finally, the use of different research techniques, such as observation, participant observation or scenarios in determining coffee consumer attitudes and their effects on the intention to drink coffee in coffee shops, will contribute further to the relevant literature.

\section{ACKNOWLEDGMENT}

This article was derived from the postgraduate thesis named 'Analysing Behaviour of Drinking Coffee in Coffee Shops in the Scope of Theory of Planned Behaviour' prepared by Bahar BAYINDIR.

\section{REFERENCES}

Acar, N., Çakırbaş, A., \& Çizmeci, B. (2019). Türk kahvesi tüketilen mekânların seçimini etkileyen faktörlerin belirlenmesi: Nevşehir örneği. Anemon Muş Alparslan Üniversitesi Sosyal Bilimler Dergisi, 7(1), 135-143.

Akarçay, E. (2012). Kah kahvehane kah cafe: Küreselleşen Eskişehir'de kahve tüketimi üzerine kurumsal bir giriş. Galatasaray Üniversitesi İletişim Dergisi, 2, 182-202.

Aksu, G., \& Karaman, H. (2016). CHAID analizi. In C. O. Güzeller (Ed.), Herkes için çok değişkenli istatistik (pp. 251-272). Ankara: Maya Akademi.

Alpar, R. (2013). Uygulamalı çok değişkenli istatistiksel yöntemler (4. Bask1). Ankara: Detay Yayıncilik.

Alyakut, Ö. (2017). Kahve markalarının bütünleşik pazarlama iletişimi bağlamında sosyal medya kullanımlar1. Afyon Kocatepe Üniversitesi Sosyal Bilimler Dergisi, 19(2), 209234.

Argan, M., Akyildiz, M., Ozdemir, B., Bas, A., \& Akkus, E. (2015). Leisure aspects of Turkish coffee consumption rituals: An exploratory qualitative study. International Journal of Health and Economic Development, 1(1), 26-36.

Aries, S., \& Eirene, K. (2015). The relationship between brand equity, customer satisfaction, and brand loyalty on coffee shop: study of excelso and starbucks. ASEAN Mark, $7(1), 14-27$.

Arun, Ö. (2013). Rafine beğeniler ya da sıradan hazlar? Türkiye' de beğeninin, ortamın ve tüketimin analizine ilişkin bir model. Kültür ve İletişim, 16(2), 45-72.

Aşık, N. A. (2017). Değişen kahve tüketim alışkanlıkları ve Türk kahvesi üzerine bir araştırma. Journal of Tourism and Gastronomy Studies, 5(4), 310-325. 
Aydın, G. A., \& Bakır, Z. N. (2016). An assessment of venues in the context of consumption culture: Consumption of kahve cafe(s) by college students. Journal of Strategic Research in Social Science (JoSReSS), 2(3), 59-84.

Aytaç, Ö. (2007). Kent mekânlarının sosyo-kültürel coğrafyası. Fırat Üniversitesi Sosyal Bilimler Dergisi, 17(2), 199-226.

Bourdieu, P. (1984). Distinction: A social critique of the judgement of taste. Cambridge: Harvard University.

Brown, N. (2018). Allegra predicts specialty segment growth in 2019 US Coffee Shop Report. Daily Coffee News. Retrieved 15 April, 2021, from https://dailycoffeenews.com/2018/10/31/allegra-predicts-specialty-segmentgrowth-in-2019-us-coffee-shop-report/

Çakı, F., \& Kızıltepe, B. (2017). Üçüncü yerler olarak kafeler ve gençlik: Balıkesir örnek olay incelemesi. Akademik Incelemeler Dergisi (AID), 12(1), 173-202.

Clausen, S. E. (1998). Applied correspondence analysis. Thousand Oaks: Sage Publications.

Coffeemag. (2016). Coffeemag, 1. Sayı. Ankara: Başak Matbaacilık.

Decrop, A., \& Snelders, D. (2005). A grounded typology of vacation decision-making. Tourism Management, 26(2), 121-132.

Demirel, B. (2010). Veri madenciliğinde chaid algoritmasının sosyal güvenlik kurumu veri tabanina uygulanması. Unpublished master's thesis, Gazi University, Ankara, Turkey.

Doğan, N., \& Özdamar, K. (2003). CHAİD analizi ve aile planlamast ile ilgili bir uygulama. Turkiye Klinikleri Journal of Medical Sciences, 23(5), 392-397.

Fendal, D. (2007). Kahve ve mutfak kültürünün dönüşümü üzerinden küreselleşme sürecinde küresel ve yerel kültürün etkileşim ve eklemlenişi. Galatasaray Üniversitesi İletişim Dergisi, 2, 148-179.

Filimonau, V., Krivcova, M., \& Pettit, F. (2019). An exploratory study of managerial approaches to food waste mitigation in coffee shops. International Journal of Hospitality Management, 76, 48-57.

Glazer, F. (2015). Seasonal beverage programme drives traffic. Nation's Restaur. News, 49(13), 112-113.

Grigg, D. (2003). The worlds of tea and coffee: Pattern of consumption". Geojurnal, 57, 283294.

Grinshpun, H. (2014). Deconstructing a global commodity: Coffee, culture, and consumption in Japan. Journal of Consumer Culture, 14(3), 343-364.

Hu, X., \& Lee, J. (2019). Emotions elicited while drinking coffee: A cross-cultural comparison between Korean and Chinese consumers. Food Quality and Preference, 76, 160-168.

Jang, Y. J., Kim, W. G., \& Lee, H. Y. (2015). Coffee shop consumers' emotional attachment and loyalty to green stores: The moderating role of green consciousness. International Journal of Hospitality Management, 44, 146-156.

Kadıŏlu, G. (2017). Tüketicilerin Türkiye'deki kahve zincirlerini tercihlerine yönelik bir karar destek modeli. Unpublished master's thesis, İstanbul Technical University, İstanbul, Turkey.

Kang, J., Tang, L., Lee, J. Y., \& Bosselman, R. H. (2011). Understanding customer behaviour in name-brand Korean coffee shops: the role of self-congruity and functional congruity. Int. J. Hosp. Manage., 31(3), 809-818.

Kanjanakom, A., \& Lee, J. (2017). Examining emotions and comparing the essende profile and the drinking experience in coffee drinkers in the natural environment. Food Quality and Preference, 56, 69-79. 
Kaptan, Y. (2013). Üçü bir arada: Melez bir mekânın kuruluşu ve Starbucks üzerine gözlemler. Kültür ve İletişim, 16(2), 73-96.

Karadaşlı, H. (2019). Motivaston temelli kültür turisti tipolojileri: Diyarbakır'a gelen yerli turistler üzerine bir araştırma. Unpublished master's thesis, Batman University, Batman, Turkey.

Kim, D., \& Jang, S. (2017). Symbolic consumption in upscale cafés: Examining Korean gen Y consumers' materialism, conformity, conspicuous tendencies, and functional qualities. Journal of Hospitality \& Tourism Research, 41(2), 154-179.

Kim, H. (2008). Importance-performance analysis of service quality in campus specialty coffee shop. J Korean Soc Food Sci Nutr, 37(8), 1069-1078.

Kim, S. E., Lee, S. M., \& Kim, K. O. (2016). Consumer acceptability of coffee as affected by situational conditions and involvement. Food Quality and Preference, 52, 124-132.

Kim, Y. W., Song, W. G., \& Lee, Y. J. (2014). A study on the consumption behaviour of coffee product according to monthly income in franchised coffee shop's consumer. Journal of the Korean Society of Food Culture, 29(6), 519-527.

Ko, W., \& Chiu, C. P. (2008). The relationships between brand attitude, customers' satisfaction and revisiting intentions of the university students-a case study of coffee chain stores in Taiwan. Journal of Foodservice Business Research, 11(1), 79-95.

Kotler, P. (2000). Pazarlama yönetimi, (Millennium Baskı). (N. Muallimoğlu, Trans.). İstanbul: Beta Yayıncilik.

Labbe, D., Sudre, J., Dugas, V., \& Folmer, B. (2016). Impact of crema on expected and actual espresso coffee experience. Food Research International, 82, 53-58.

Limón-Rivera, R., Mejía-Ochoa, F. J., Peláez-Muñoz, E. C., Vargas-Rivera, Y., HernándezVelásquez, S., Fierro-Domínguez, E., ... \& González-Pérez, M. (2017). Analysis of the relationship between lifestyle and coffee consumption habits, from the myth approach, in the municipalities of Orizaba, Tehuipango, and Zongolica Veracruz. International Journal of Advanced Engineering, Management and Science, 3(12), 239945.

Manzo, J. (2014). Machines, People, and Social Interaction in "Third-Wave" Coffeehouses. Journal of Arts and Humanities, 3(8), 1-12.

Nadiri, H., \& Günay, G. N. (2013). An empirical study to diagnose the outcomes of customers' experiences in trendy coffee shops. Journal of Business Economics and Management, 14(1). 22-53.

Oldenburg, R. (1989). The great good place; cafes, coffee shops, bookstores, bars, hair salons and other hangouts at the heart of a community. Cambridge: Da Capo Press.

Özcan, D. (2016). "Popüler kahve çeşitleri nelerdir". Retrieved 14 April, 2021, from http://iyi21.com/iyi-beslen/populer-kahve-cesitleri-nelerdir.

Phillip, S., Hunter, C., \& Blackstock, K. (2010). A typology for defining agritourism. Tourism management, 31(6), 754-758.

Pozos-Brewer, R. (2015). Coffee shops: Exploring urban sociability and social class in the intersection of public and private space. Unpublished bachelor degree thesis, Dept. of Sociology \& Anthropology, Swarthmore College, USA. 10.13140/RG.2.2.19087.43680

Said, I. (2012). Coffee shops and modern lifestyle in Makassar, Indonesia. Northern Illinois University, Working Paper, 1-16.

Samoggia, A., \& Riedel, B. (2018). Coffee consumption and purchasing behavior review: Insights for further research. Appetite, 129, 70-81.

Sarıtaş, E., \& Barutçu, S. (2016). Tüketici davranışlarının analizinde kuşaklar: Sosyal medya kullanımı üzerinde bir araştırma. Pamukkale Journal of Eurasian Socioeconomic Studies, 3(2), 1-15. 
Schüßler, L. (2009). Protecting 'Single-origin coffee'within the global coffee market: The role of geographical indications and trademarks. Estey Centre Journal of International Law \& Trade Policy, 10(1), 149-185.

Shaker, R., \& Rath, J. (2019). The coffee scene in Glasgow's West End: On the class practices of the new urban middle classes. City, Culture and Society, 17, 1-7.

Şimşir, T. E. (2018). Internetten alişveriş yapan tüketicilerin tipolojisi. İstanbul Ticaret Üniversitesi Sosyal Bilimler Dergisi, 17(33), 173-207.

Spence, C., \& Carvalho, F. M. (2020). The coffee drinking experience: Product extrinsic (atmospheric) influences on taste and choice. Food Quality and Preference, 80, 103802.

Susanty, A., \& Kenny, E. (2015). The relationship between brand equity, customer satisfaction, and brand loyalty on coffee shop: Study of Excelso and Starbucks. ASEAN Marketing Journal, 7(1), 14-27.

Tucker, M. C. (2011). Coffee culture; local experiences, global connections. New York: Routledge.

Typaldos, C. (2016). Experiencing the Starbucks experience-a cultural analysis of the effects of glocalization. Unpublished master's thesis, Lund University, Sweden.

Wakefield, K. L., \& Blodgett, J. G. (1996). The effect of the servicescape on customers' behavioral intentions in leisure service settings. Journal of Services Marketing, 10(6), 45-61.

White, M. (2012). Coffee life in Japan. California: University of California Press.

Woldoff, R. A., Lozzi, D. M., \& Dilks, L. M. (2013). The social transformation of coffee houses: the emergence of chain establishments and the private nature of usage. International Journal of Social Science Studies, 1(2), 205-218.

Yan, M., \& Li, Q. (2016). Consumer behavior in coffee drinking: Comparison between Chinese and Swedish university students. Unpublished bachelor degree thesis, University of Gavle, Sweden.

Yazıcı, B. (2018). Yeni lüks kavramı bağlamında y kuşağı ile evrilen tüketim ve y kuşağının lüks kavramına bakışı. Kocaeli Üniversitesi Sosyal Bilimler Dergisi, (36), 95-112.

Yıldıztekin, B. (2016). Uyum ve uygunluk analizleri. In C. O. Güzeller (Ed.), Herkes için çok değ işkenli istatistik (pp. 273-302). Ankara: Maya Akademi.

Yu, H. \& Fang, W. (2009). Relative impacts from product quality, service quality, and experience quality on customer perceived value and intention to shop for the coffee shop market. Total Qual. Manage. Bus. Excell., 20(11), 1273-1285.

Zhang, M., Kim, P. B., \& Goodsir, W. (2019). Effects of service experience attributes on customer attitudes and behaviours: The case of New Zealand café industry. Journal of Hospitality Marketing \& Management, 28(1), 28-50 